Iza Desperak

Uniwersytet Łódzki

\title{
Chłopcy przebrani w sukienki, czyli założycielski mit polskiej krucjaty antygender
}

\begin{abstract}
Wstęp
Tekst ten nawiązuje do krucjaty antygender, która rozpoczęła się w Polsce jesienią 2013 roku, i od tego czasu doczekała się licznych analiz. W tak krótkim wydawałoby się czasie udało mi się nawet wypromować pracę magisterską poświęconą temu zagadnieniu (Felczak 2014). Jednak na wstępie należy zauważyć, że fenomen ten nie ograniczał się do Polski, występuje $\mathrm{w}$ wielu krajach zarówno wschodniej, jak i zachodniej Europy, a także na innych kontynentach, więc nie wystarczy mu się przypatrywać z lokalnej perspektywy. Doniesienia o chłopcach przebieranych na siłę w sukienki pojawiły się we Francji, na Ukrainie odbyła się konferencja o gender i antygender, a prezydent Ekwadoru Rafael Correra (2014) poświęcił swe noworoczne wystąpienie zagrożeniom stwarzanym przez rzekomą "ideologię gender".

W Polsce tymczasem "gender" stało się słowem roku 2013, co wzbudziło mieszane uczucia w badaczach i badaczkach wprowadzających je do dyskursu od lat co najmniej kilkunastu. Wyszukiwarka Biblioteki Narodowej podawała w tym samym czasie ponad 160 wyników wyszukiwania według tego słowa-klucza. Niestety, Encyklopedia Gender, wydawnictwo przygotowywane od kilku lat, ukazała się dopiero w 2014 roku, a więc już po owym medialnym szumie. Czy nieco większa liczba szeroko dostępnych wydawnictw wyjaśniających, do czego odnosi się termin gender, zmieniłaby cokolwiek wobec otoczki medialnej sensacji, jaka zaczęła mu towarzyszyć, i która odpowiada za niezwykłą karierę tego pojęcia?
\end{abstract}

\section{Fenomen sporu o gender w Polsce}

Zjawisko medialnego fenomenu nagłej popularności słowa "gender" oraz nagonki na rzekomą "ideologię gender" uprawianą jakoby przez "genderystów" wyjaśniano na gruncie polskim na wiele sposobów. Najczęściej zwracano uwagę, że 
krucjatę przeciwko gender rozpętał Kościół katolicki tuż po ujawnieniu skandali pedofilskich i wyjaśniano, że miało to odwrócić uwagę publiczności od tego niewygodnego zjawiska.

Analizując to zjawisko, można też nawiązać do sporu między konserwatyzmem i liberalizmem czy postępowością oraz wcześniejszych ataków na inne grupy, będące uosobieniem nowoczesności i modernizacji, ze strony konserwatystów. Wszelkie liberalne działania byłyby więc poddawane krytyce ze strony konserwatystów, i edukacja równościowa byłaby tu kolejnym celem ataku. Dodatkowo wiele konserwatywnych krucjat jest nacechowanych lękami związanymi z płcią i seksualnością, a edukacja genderowa kojarzy się z tym właśnie zakresem. Od początku transformacji obserwujemy, jak kwestie związane z płcią dzielą opinię publiczną. Zwłaszcza radykalna prawica, wspierana przez skrajne ruchy nacjonalistyczne, redefiniuje wciąż postać zbiorowego wroga, jednocześnie kozła ofiarnego (Girard 1991). Przed II wojną światową rolę kozła ofiarnego pełnili Żydzi. Dyskurs antysemicki, choć wciąż się odradza, przybiera też nowe formy, jak dyskurs homofobiczny, na co zwrócił uwagę Adam Ostolski (2005). Silny ruch przeciwko integracji z Unią Europejską, który ujawnił się w Polsce w pierwszej dekadzie XXI wieku, posługiwał się z kolei retoryką, w której antykoncepcja i aborcja wyznaczają ramy cywilizacji śmierci, a którą z kolei uosabia Unia Europejska. Kozłami ofiarnymi stają się więc mniejszości seksualne i ruchy na rzecz ich równouprawnienia, oraz idee równości kobiet i mężczyzn, skrótowo sprowadzanej do walki o prawa reprodukcyjne czy parytety płci.

W okresie poprzedzającym wstąpienie Polski do Unii Europejskiej można było zaobserwować, jak po stronie unijnych sceptyków czy wręcz wrogów integracji pojawiła się frazeologia utożsamiająca euroentuzjastów z "cywilizacją śmierci", oznaczającą antykoncepcję, aborcję, eutanazję oraz związki jednopłciowe (Desperak 2003). Początkowo eurosceptycy byli identyfikowani z Kościołem katolickim, stąd sukces polskiego rządu w przeprowadzeniu eurointegracji opierał się na zawarciu porozumienia, w którym ówczesny rząd obiecał utrzymanie rzekomego kompromisu aborcyjnego w zamian za kościelne poparcie unijnego projektu. Temu właśnie przymierzu tronu z ołtarzem sprzeciwiały się wówczas sygnatariuszki „Listu stu kobiet”, wystosowanego w 2002 roku przez organizacje kobiece do Parlamentu Europejskiego (List Stu Kobiet 2002). Nieprzejednane i niezagrożone niczym stanowisko Kościoła sprawiło, że do listy tych „wrogów” nieco później dołączyło zapłodnienie in vitro. A jeszcze później gender.

Polską nagonkę na gender tłumaczy się dość często, odwołując do teorii paniki moralnej, mobilizacji społeczeństwa wobec rzekomych zagrożeń godzących w fundamentalne wartości - tu rzekoma ideologia gender przebierająca chłopców $\mathrm{w}$ sukienki grozi oczywiście przymusową zmianą płci owych małych bezbronnych chłopców. Panika moralna w Polsce Anno Domini 2013 odwołuje się więc do Seksmisji, filmu z 1983 roku, organizującego do dziś dyskurs dotyczący płci, oparty na lęku przed feminizmem i kompleksie kastracyjnym. Film ten dziś ma większą widownię niż w latach 80. , i być może dla większości społeczeństwa stanowi jedyny przekaz dotyczący genderowych relacji w społeczeństwie. 
Fenomen polskiej krucjaty przeciwko gender wyjaśniano też na wiele innych sposobów. Używany przeze mnie konsekwentnie termin „krucjata” zwraca uwagę na głównego aktora tego fenomenu, czyli Kościół katolicki. W przypadku polskiej nagonki na gender to Kościół był inicjatorem, a księża i biskupi głównymi rozgrywającymi. W niedzielę 30 grudnia 2013 roku we wszystkich kościołach katolickich odczytano list biskupów przeciwko gender (Episkopat 2013). Jednym $\mathrm{z}$ najczęściej wypowiadających się przeciwko gender w mediach był z kolei ksiądz Dariusz Oko, który w tym samym czasie wydał książkę na ten temat (Oko 2014). Jednak nie tylko funkcjonariusze Kościoła uczestniczyli w nagonce na gender, a spór o gender toczył się nie w katolickich, ale mainstreamowych, także publicznych, mediach.

\section{Światowa nagonka na gender}

O tym, że Kościół katolicki ma nie tylko powody do atakowania rzekomej ideologii gender, ale wręcz plan w tym zakresie, przekonuje Judith Butler. W Końcu różnicy seksualnej opisuje ona między innymi pewien spór między uczestniczkami i uczestnikami IV Światowej Konferencji w sprawie Kobiet, która pod egidą ONZ odbyła się w Pekinie w 1995 roku. Spór ten dotyczył użycia w końcowym dokumencie pewnych sformułowań, jego wynikiem była zgoda na użycie terminu „płeć kulturowa”, czyli gender, i pominięcie słowa „lesbijka” (Butler 2012). Być może obecni tam przedstawiciele zaproszonych krajów, w tym także delegacje reprezentujące sojusz tronu z ołtarzem, zinterpretowali tamtejsze dyskusje jako wprowadzenie kwestii praw lesbijek pod płaszczykiem niezrozumiałego hasła gender do oficjalnego języka ONZ. Watykan musiałby wtedy zająć negatywne stanowisko wobec owego zjawiska i przekazać odpowiednie instrukcje na szczeble krajowe, a stanowisko polskich biskupów byłoby rezultatem takiego postępowania. Kościelna krucjata przeciwko gender byłaby więc efektem pewnego nieporozumienia, i w rzeczywistości skierowana byłaby przeciwko ruchom LGBT, a jej polska wersja byłaby zaś tylko częścią szerszego, niemal globalnego, watykańskiego planu. Choć trudno uwierzyć, że wydarzenia sprzed lat osiemnastu mogą tłumaczyć to, co stało się w roku 2013 w Polsce, to akurat Kościół katolicki jest instytucją, która może sobie pozwolić na działanie w takim tempie. Wiele wskazuje też na to, że lęk przed rzekomym zagrożeniem ze strony gender jest podszyty homofobią oraz transfobią.

Bardziej uniwersalny wymiar tego zjawiska pokazano na konferencji poświęconej ruchom gender i antygender w Kijowie ${ }^{1}$. Ukraina to kraj, gdzie wpływ Watykanu nie sięga, jednak także ona doświadczyła wojny o gender. Być może akurat w tym zakresie Kościoły rzymskokatolicki i prawosławny świetnie się dogadują,

\footnotetext{
1 Publikacje z tej konferencji znaleźć można w tematycznym numerze „Гендер и антигендер” Гендерхий журнал „,Я" 2013, No. 4 [http://ua.boell.org/uk/2013/12/30/gender-i-antigender-genderniyzhurnal-ya-no4-34-2013].
} 
w sąsiedniej Rosji to właśnie Cerkiew wydaje się pełnić podobną rolę w dyskursie politycznym.

Z kolei tezę Butler o watykańskim wątku w krucjacie przeciwko gender potwierdzają doniesienia $\mathrm{z}$ niedawnego watykańskiego synodu poświęconego rodzinie. W jednym z jego oświadczeń pojawiło się sformułowanie, że „ideologia gender zmierza do legalizacji małżeństw homoseksualnych" (Bielecki 2014).

Celem tego tekstu nie jest jednak analiza fenomenu krucjaty antygender, lecz jedynie jednego z jego elementów. Przypomnijmy więc, że w Polsce zaczęło się wszystko od doniesień o przedszkolu, gdzie miano za pieniądze z Unii Europejskiej przebierać na siłę chłopców w sukienki. Doniesienia te wywołały falę dyskusji, gdzie po jednej stronie oskarżano o deprawację nieletnich, a po drugiej ostrożnie dementowano. Wprawdzie okazało się w końcu, że w rzeczywistości nie przebierano chłopców w sukienki, lecz ów mit założycielski antygenderowej krucjaty poszedł w świat. Także we Francji pojawiły się podobne newsy. Protesty $\mathrm{w}$ tym kraju dotyczyły jednak raczej inicjatyw równościowych w edukacji, a odpowiedzią na nie stało się świadome niewymuszone przywdziewanie przez uczniów spódnic w proteście przeciwko dyskryminacji ze względu na płeć ('Boys in skirts' plan sparks standoff at French school). Doniesienia o rzekomych nadużyciach zwolenników gender wciąż się pojawiają tu i tam, w 2014 roku łamach „Naszego Dziennika" demaskowano kolejną aferę (Nasz Dziennik: Szóstka za gender). Wydaje się, że mamy do czynienia z pewnym powtarzalnym wzorem.

\section{O co chodziło w polskim sporze o gender}

W sporze o gender wyróżnić można dwie strony. Po jednej stronie znajdują się przeciwnicy rzekomej ideologii gender, z Kościołem katolickim na czele. Po drugiej stronie znajdują się rzekomi genderyści. Ten podział, odnotowany we wszystkich analizach owego sporu, nie do końca się sprawdza, gdy przyjrzymy mu się z perspektywy owego mitu założycielskiego o chłopcach przebieranych $\mathrm{w}$ sukienki. Choć przeciwnicy gender twierdzą, że do inkryminowanego zdarzenia doszło, a zwolennicy dokładają starań, by ów mit obalić, nie różnią się oni pod jednym względem: dla jednych i drugich chłopcy przebrani w sukienki są niewyobrażalnym horrendum. To, co działo się wokół gender w 2013 roku trudno uznać za debatę. Po jednej stronie znalazły się irracjonalne i pełne nienawiści komunikaty, być może podszyte lękiem, i na pewno odwołujące się do lęków. Do lęku przed seksualną i genderową odmiennością, jaką uosabiała historia o przedszkolakach przebieranych na siłę w sukienki, a także do obawy przed zmianą tego, co wydaje się naturalne i odwieczne, a więc tradycyjnych definicji męskości i kobiecości. Wedle antygenderystów edukacja równościowa, przeciwko której chcą oni zmobilizować publiczność, jest zagrożeniem dlatego, że kwestionuje ów tradycyjny podział ról. Wedle katolickich księży kwestionuje ona boskie prawo, tak samo jak procedura zapłodnienia in vitro. Wedle tradycjonalistów narodowa tradycja wyznacza definicje rodziny i ról jej członków, i nie należy w nią ingerować, 
nawet gdy chodzi o przeciwdziałanie przemocy w rodzinie. Antygenderyści w tym starciu używali innego, racjonalnego języka, unikali nawoływania do nienawiści, cierpliwie wyjaśniali, że nie w tym przedszkolu, że nie przebierali, że nie na siłę. Przyjmując tę jedyną chyba racjonalną strategię w obliczu nagłego wybuchu nagonki na gender, przegrali jednak, bowiem równie silnie jak antygenderyści sprzeciwiali się wizji chłopców w sukienkach. Choć nie opowiadali się za zachowaniem tradycyjnego podziału ról, próbowali (i próbowaliśmy) gasić emocje, przekonując, że nic takiego nie przyszłoby im (nam?) do głowy.

A co by się stało, gdyby się okazało, że gdzieś jednak chłopcy zakładają sukienki? Przecież w jednym z przedszkoli mówiono o Szkotach noszących kilty, gdzie indziej chłopcy, przebierając się za stylistów, zakładali fartuszki. Dwie dekady temu identyczne fartuszki nosili w przedszkolu chłopcy i dziewczynki, i nikt nie robił $z$ tego problemu. Zamieszczane przez internautów memy z niemowlęcym Karolem Wojtyłą w czymś w rodzaju sukienki przypominają, że jeszcze dawniej był to strój właściwy dla niemowląt bez względu na płeć. W międzyczasie wyobrażenie kilkuletniego chłopca w sukience stało się groźną bronią.

Obawę przed przebieraniem chłopców w sukienki najlepiej reprezentuje ksiądz Dariusz Oko. W wywiadzie rzece podzielił się swym traumatycznym doświadczeniem z dzieciństwa - musiał donaszać ubrania po starszych siostrach (Varga 2014). Jednak mniej straumatyzowana część polskiego społeczeństwa powinna być słabiej uczulona na doniesienia o przebieraniu chłopców w sukienki.

Przebieranie chłopców w sukienki nie tylko budzi lęki homofobiczne i transfobiczne. Uderza w jeden z ostatnich bastionów społecznego definiowania męskości i kobiecości poprzez kostiumy, tak jak uderzają w nie teoria i praktyki queer (co bynajmniej nie prowadzi do zrównania obu form ataku). O ile rozważamy kwestię równości kobiet i mężczyzn, musimy dostrzec jeden $\mathrm{z}$ istotnych wymiarów nierówności, dotyczący mężczyzn.

O ile kobiety (od kilkudziesięciu lat) mogą wybierać między sukienką, spódnicą i spodniami, to mężczyznom nadal odmawia się tego wyboru. Mężczyźni wybierający inny niż spodnie strój są zawsze niemal klasyfikowani jako nienormatywni, choć wymiary owej nienormatywności są zróżnicowane. To etniczni Inni, tak Szkoci, jak i mieszkańcy Azji, noszący tradycyjne stroje, czy nawet mieszkańcy południowej Europy. Bo tylko środkowo-europejska tradycja męskiego stroju przywołuje spodnie. Zresztą spodnie noszono tu długo pod spód, jako element spodniej, intymnej garderoby, i jedynie wystawały spod dłuższych szat lub chłopskiej kapoty. Na polski strój szlachecki, zaadaptowany z Turcji, składały się szarawary, spodnie, które na Bałkanach nosiły także kobiety. Męski strój niemiecki wymagał z kolei pończoch, kojarzonych dziś z kobiecym strojem, a angielski renesansowy dżentelmen nosił do nich spodnie niewiele mające wspólnego ze współczesną definicją. W czasach, gdy "królowa hiszpańska nie miała nóg”, angielski król Henryk Ósmy portretowany był przez Hansa Holbeina w czymś, co dzisiejszym pogromcom gender by się nie spodobało. 
Z kolei południowo-wschodnia Europa wciąż kultywuje tradycję męskich "spódniczek" w jak najbardziej męskim wydaniu stroju, czyli uniformie gwardii honorowej pełniącej wartę przy grobie nieznanego żołnierza w Atenach.

Tak jak mężczyznom i chłopcom dziś przypisujemy spodnie, i nie dopuszczamy myśli, że mogłoby być inaczej, tak kobietom i dziewczętom odmawiano prawa do spodni jeszcze kilka pokoleń wstecz. Nasze matki, babcie i prabababcie pamiętają jeszcze, jakie problemy miały kobiety w spodniach. Kobiety jednak uzyskały prawo do wyboru garderoby, i można się spodziewać, że mężczyźni też będą mogli wybierać swobodnie ubiór. I nie musi to bynajmniej oznaczać swobodnego wyboru płci biologicznej, czym straszy nas krucjata antygender. Te dwie kwestie należy rozdzielić. A także jasno zadeklarować, że w społeczeństwie demokratycznym jest miejsce także dla osób transpłciowych, którymi straszą nas opowiadacze bajek o genderowych przedszkolach. Jak i różnych alternatywnych tożsamości płciowych, jak choćby osoba transgender czy crosdresser.

Przeciwnicy gender straszą nas zagrożeniem dla tradycyjnej męskości, tradycyjnego podziału ról i rozmycia tradycyjnej definicji seksualności. No cóż, procesy te właśnie trwają. Kobiety pracują w męskich zawodach, mężczyźni biorą urlopy ojcowskie. Pary hetero korzystają z technologii medycznych, by zostać rodzicami, a pary jednopłciowe wychowują dzieci $\mathrm{w}$ rodzinach $\mathrm{z}$ wyboru (Mizielińska, Abramowicz, Stasińska 2014).

Równościowa rewolucja, proces opisywany przez czołowych badaczy spolecznych, jak Manuel Castells (2009), Anthony Giddens (2006), Roland Inglehart i Pippa Norris (2009), dotyczy zarówno kobiet, jak i mężczyzn. Wedle tych badaczy obserwujemy właśnie zmierzch społeczeństwa opartego na zasadzie patriarchatu, głównie dzięki zmianie pozycji kobiet, ale także dzięki przejęciu przez nie kontroli nad reprodukcją oraz ruchowi feministycznemu i na rzecz praw LGBT.

Społeczna definicja mężczyzny i męskość były fundamentem patriarchatu, z ideologią maczyzmu i wizerunkiem "prawdziwego mężczyzny", uosabianego w kulturze masowej przez „Marlboro Man”. To kultura masowa odpowiedziała na zmianę i włączyła się w nią, proponując postać "nowego mężczyzny” (Melosik 1996; Dzido 2003), później mężczyzny metroseksualnego, którego kolejnym wcieleniem może być mężczyzna „drwaloseksualny"2. Inną alternatywą dla tradycyjnego wzorca męskości jest też crossdresser, czyli mężczyzna ubierający się niezgodnie ze społecznym oczekiwaniem, oraz drag queen queer. Nikt $z$ nich nie ma na sobie spodni. A sukienka na mężczyźnie zarezerwowana została zdaniem antygenderystów dla jednego tylko modelu męskości, mężczyzn ślubujących celibat w Kościele katolickim.

2 Tak polskie media ochrzciły lokalny odpowiednik 'lumbersexual' man, por. reportaż TV http://dziendobry.tvn.pl/wideo,2064,n/mezczyzna-drwaloseksualny-marzenie-niejednej-kobiety,1497 27.html, tekst http://natemat.pl/124099,zapomnij-o-metroseksualnych-chlopakach-nowy-trend-to-lu mbersexual; trend ten odnaleźć można na męskich blogach poświęconych modzie i pielęgnacji zarostu: http://www.ekskluzywnymenel.com/; http://www.facetemjestem.pl/kosmetyki-do-pielegnacji-brody/, http://casualism.pl/broda-zarost-czym-mity-fakty/. 
Nie chodzi tu o sukienkę, która jest tylko symbolem. Chodzi o model męskości, przekazywany w toku socjalizacji. Model, który od chłopców wymaga więcej niż od dziewczynek. Dziewczynki socjalizuje się w zgodzie z kobiecością, która je otacza w dzieciństwie, socjalizacja chłopców wymaga odcięcia się od tej kobiecości (Bardwick, Douvan 1982). Gdy dziewczynka sięga po mamine ubrania i kosmetyki, to jest to akceptowany model wchodzenia w kobiecość, choć jeszcze niedawno makijaż u nastolatek był nieakceptowany społecznie. Gdy chłopiec próbuje tego samego, najczęściej jest mocno zniechęcany, bo socjalizacja chłopca to nie tylko zaprzeczenie w sobie dziecka, ale także kobiety i homoseksualisty, jak twierdzi Élisabeth Badinter (1993), żeński strój uosabia zaś oba zagrożenia. Ale tak naprawdę lęk przed przemodelowaniem męskości budzić powinna grafika Marty Frey, przedstawiająca dwóch bardzo męskich mężczyzn, bynajmniej nie w sukienkach, tylko w najbardziej maczo pozach na siłowni, w rolach „nowych mężczyzn”, którzy po sesji na siłowni muszą ,jeszcze zrobić zakupy i zrobić obiad, zanim Mariolka wróci z pracy".

Jako trenerka/edukatorka równościowa, gdy usłyszałam po raz pierwszy o genderowym przedszkolu, gdzie chłopców przebierano jakoby w sukienki, wpadłam w panikę, wyobraziłam sobie podobną nagonkę w związku z moją działalnością i zaczęłam opracowywać scenariusze ewentualnej obrony. Wyobraziłam sobie też sytuację, w której oskarżenie nie jest tak bezpodstawne - na zajęciach z młodzieżą rysujemy postaci męskie i żeńskie, a następnie zamieniamy im atrybuty ról płciowych (tych genderowych zazwyczaj). Zdarzyło się mi raz przynajmniej spotkać na takich zajęciach osobę, której płeć nie była oczywista, i pewnie parę razy przegapić podobne sytuacje. A co, gdyby trafił się chłopiec w sukience? Albo w różowej sukience? Albo pragnący bawić się lalkami? Ten katalog edukatorskich lęków pokazuje, jak bardzo się boimy nieznanego i jak mało jesteśmy przygotowani na to, co się dzieje z gender w realnym świecie, a nie dyskursie politycznym.

\section{Równościowe przedszkole}

Moją perspektywę całkowicie zmienił film dokumentalny pt. Równość płci po szwedzku (http://www.planeteplus.pl/dokument-rownosc-plci-po-szwedzku_42499), emitowany przez stację telewizyjną Planete. Przedstawia on pewne przedszkole w Szwecji, którego misją jest edukacja do równości. Wychowawczynie podkreślają, że chodzi im o płeć kulturową, czyli gender, a nie biologiczną, i że nie planują zmieniać orientacji seksualnej wychowanków. Czy taka deklaracja powstrzymałaby polskich antygenderystów przed atakiem, gdyby się dowiedzieli o takiej działalności?

W szwedzkim przedszkolu, które nosi znamienną nazwę Egalia, rodzice i wychowawczynie dyskutują o tym, jak realizować ideę wychowania do równości. 
Dzieci uczą się używania nowego nienacechowanego płciowo zaimka hen ${ }^{3}$, nieużywanego przedtem w języku szwedzkim jako zaimek osobowy. Jeden z przedszkolaków, chłopiec o imieniu Justus, przysyła z wakacji swoje zdjęcie w sukience, i wychowawczynie podejmują ten temat. Okazuje się, że Justus w domu też czasem zakłada sukienkę starszej siostry. Inny chłopiec lubi kolor różowy i fioletowy, choć ważniejsze jest dla niego założenie dwóch różnych skarpetek, a dla jego rodziców zapytanie o to, które skarpetki woli. Akurat rodzice tego chłopca to dwie mamy, ale nie robi to na nim wielkiego wrażenia. Inne dziecko, jeszcze na ręku u taty, i ze smoczkiem w buzi, spotykamy w sklepie z zabawkami, gdzie tata kupuje mu lalkę. Tamtejszy pełnomocnik do spraw równości odwiedza przedszkole i dziwi się, że więcej uwagi niż do kwestii równości przywiązuje się tam do szacunku dla podmiotowości dziecka.

W zestawieniu z tym równościowym przedszkolem polska panika wobec programów edukacji równościowej w przedszkolach wydaje się niezbyt trafnie skierowana. Z drugiej strony, nie tylko przeciwnicy edukacji genderowej odżegnywali się od pomysłu przebierania chłopców w sukienki. Po zapoznaniu ze szwedzkim przykładem dobrej praktyki w tym zakresie należy nam się chwila refleksji nad tym, czy jest się czego bać.

\section{Literatura:}

'Boys in skirts' plan sparks standoff at French school, materiał France24: http://www.France24.com/en/20140515-boys-skirts-plan-sparks-standoff-french-school-sexism-genderprotest/

„Гендер и антигендер" - Гендерхий журнал „Я“ 2013, No. 4, http://ua.boell.org/uk/ 2013/12/30/gender-i-antigender-genderniy-zhurnal-ya-no4-34-2013

Badinter E., 1993, XY, tożsamość́mężczyzny, Wydawnictwo W.A.B., Warszawa.

Bardwick A.E., Douvan E., 1982, Ambiwalencja. Socjalizowanie kobiet [w:] T. Hołówka (red.), Nikt nie rodzi się kobieta, Wydawnictwo Czytelnik, Warszawa.

Bielecki T., Homodylemat synodu w Watykanie, "Gazeta Wyborcza” 14.10.2014, http://wyborcza.pl/1,76842,16798666,Homodylemat_synodu_w_Watykanie.html.

Butler J., 2012, Koniec różnicy seksualnej [w:] A. Gajewska (red.) Teorie wywrotowe, Antologia przektadów, Wydawnictwo Poznańskie, Poznań.

Castells M., 2009, Koniec tysiaclecia, Wydawnictwo Naukowe PWN, Warszawa.

Desperak I., 2003, Antykoncepcja, aborcja i ... eutanazja. O upolitycznieniu praw reprodukcyjnych $w$ Polsce, Acta Universitatis Lodziensis, Folia Sociologica t. 30.

Dzido D., 2003, Mężczyzna do oglądania, „Atrmix” nr 5, artmix http://free.art.pl/artmix.

Felczak A., 2014, Analiza zjawiska w dyskursie publicznym - funkcjonalna dyskusja wokót gender, która przykuła uwagę odbiorców mediów, na podstawie analizy treści przekazów masowych wybranego portalu internetowego, praca magisterska pod kierunkiem I. Desperak, Łódź.

Giddens A., 2006, Przemiany intymności. Seksualność, mitość i erotyzm we wspótczesnych społeczeństwach, Wydawnictwo Naukowe PWN, Warszawa.

3 Oryginalny francuski tytuł tego dokumentu się do tego odwołuje w tytule: Ille, el, hen: (http://www.arte.tv/guide/fr/048395-000/il-elle-hen). 
Girard R., 1991, Kozioł ofiarny, Wydawnictwo Łódzkie, Łódź.

Inglehart R., Norris P., 2009, Wzbierająca fala: równouprawnienie ptci a zmiana kulturowa na świecie, Państwowy Instytut Wydawniczy, Warszawa.

List pasterski na Niedzielę Świętej Rodziny, http://episkopat.pl/dokumenty/5545.1,List_pasterski_na_Niedziele_Swietej_Rodziny_2013_roku.html.

List Stu Kobiet, http://www.zgapa.pl/zgapedia/List_Stu_Kobiet.html.

Melosik Z., 1996, Tożsamość, ciało i władza: teksty kulturowe, jako (kon)teksty pedagogiczne, Wydawnictwo Edytor, Poznań.

Mizielińska J., Abramowicz M., Stasińska A., 2014, Rodziny z wyboru w Polsce, Życie rodzinne osób nieheteroseksualnych, Instytut Psychologii PAN, Warszawa.

Nasz Dziennik: Szóstka za gender: http://wyborcza.pl/1,91446,17080675,_Nasz_Dziennik Szostka_za_gender.html.

Oko D. (red), 2014, Dyktatura gender, Wydawnictwo Biały Kruk, Kraków.

Ostolski A., Żydzi, geje i wojna Cywilizacji: op.cit, nr 23 (2/2005): http://www.opcit.art.pl/ cms/index.php?p=text23_01.

Rafael Correa rechaza la absurda y peligrosisima ideologia, de genero, infobae, z 3 stycznia 2014 r, http://www.infobae.com/2014/01/03/1534727-rafael-correa-rechaza-la-absurda-y-peligrosisima-ideologia-genero zapis wystąpienia: https://www.youtube.com/watch? $\mathrm{v}=\mathrm{Kt}$ A6VUQD4Js [dostęp: 27.12.2014].

Varga K., Łaska pychy, czyli Oko kocha, Oko walczy: http://m.wyborcza.pl/wyborcza/1,132748, 15809621.html.

\section{Summary}

Boys dressed up as girls, or Polish anti-gender crusade

Paper recollects the beginning of Polish anti-gender crusade, started in 2013 with the story on boys pressed to wear dresses in one of kindergartens. It presents various approaches to the phenomena of public debate on gender, and various interpretations, on both local and global level, including Judith Butler's theory of a Vatican reaction onto the Fourth World Conference in Beijing in1995. It focuses on the analysis of the primary [faked] story and its significance and situates it in the context of redefining masculinity patterns. It also points out how traditional definition of masculinity is mixed with heteronorma, and both of them seem to be dangerous by the opponents of gender education.

\section{Keywords}

gender, anti-gender, education, kindergartens, masculinity, trousers

\section{Słowa kluczowe}

gender, anty-gender, wychowanie przedszkolne, edukacja, męskość, spodnie 
